ISSN: 0514-7336 — ISSN electrónico: 2386-3943

DOI: https://doi.org/10.14201/zephyrus202188193207

\title{
ARCHAEOMETRIC STUDY OF PICTORIAL STRATIGRAPHIES FROM A TOGATUS ROMAN SCULPTURE FOUND IN SALAMANCA (SPAIN)
}

\section{Estudio arqueométrico de estratigrafías pictóricas de una escultura romana de un togatus encontrada en Salamanca (España)}

Jorge Souto*, Javier Pinto*, Ángel Carmelo Prieto*, Mercedes Barrera**, Manuel Carlos JimÉnez ${ }^{* * *}$ y Alma Salinas****

* Dpto. de Física de la Materia Condensada, Cristalografía y Mineralogía. Univ. de Valladolid. Paseo de Belén, 7. 47011 Valladolid.E-mail:souto@eii.uva.es; jpinto@fmc.uva.es; angelcarmelo.prieto@uva.es. ORCIDID: https://orcid. org/0000-0002-3676-1712; https://orcid.org/0000-0003-3155-8325; https://orcid.org/0000-0003-4275-0849

** Laboratorio de Análisis de los Materiales. Centro de Conservación y Restauración de Bienes Culturales-Junta de Castilla y León. Cl Carretera, 2. 47130 Simancas (Valladolid).E-mail: kimrest@hotmail.com. ORCID ID: https:// orcid.org/0000-0001-6087-7515

*** Estudio de Arqueología. Cl Gütenberg, 16, bajo 2. 37007 Salamanca. E-mail: manueljimenez@usal.es. ORCID ID: https://orcid.org/0000-0002-2074-9428

**** Museo de Salamanca. Patio de las Escuelas, 2. 37008 Salamanca. E-mail: almacecilia.salinas@jcyl.es. ORCID ID: https://orcid.org/0000-0002-3969-229X

Recepción: 13/01/2021; Revisión: 23/05/2021; Aceptación: 23/05/2021

AвSTRACT: The decoration of a togatus Roman sculpture found in Salamanca in 2015 has been examined to identify the applied pigments. The study was performed using environmental scanning electron microscopy -ESEM- with an energy-dispersive X-ray analyser -ESEM-EDX- and Raman spectroscopy -RS- in microscopic mode. The ESEM-EDX analyser allowed the elemental chemical composition of the samples to be established, the concentration and distribution of each element in areas and cross-sections to be determined, and predefined concentration profiles in the pictorial stratum to be obtained. The ionic or molecular phases of the components in the pictorial material were identified by Raman spectroscopy. Therefore, the pigments that make up the pictorial palette of this artwork, such as iron oxides or carbon black, have been ascertained by means of these complementary techniques. The structural substrate, as well as the chemical nature of the dispersing/priming materials for the colourants, have been additionally characterised. Silica and aluminosilicates have been found to be present in combination with both the iron oxides and carbon black.

Key words: Pigments; Classical Sculpture; Polychromy; Dispersants; Marble; Raman Spectroscopy; ESEM-EDX.

Resumen: La decoración de una escultura de togado romana encontrada en Salamanca en 2015 ha sido examinada con el objeto de identificar los pigmentos utilizados. Para ello se ha empleado microscopía electrónica de barrido -ESEM- equipada con un analizador de espectroscopía de rayos X por dispersión de energía -ESEMEDX- y espectroscopía Raman -RS- en modo microscópico. El análisis mediante ESEM-EDX permitió establecer 
la composición química elemental de las muestras; determinar la concentración y la distribución de cada elemento en diferentes áreas y secciones transversales, y obtener perfiles de concentración predefinidos en el estrato pictórico. Las fases iónicas o moleculares de los componentes presentes en los materiales pictóricos fueron identificadas mediante espectroscopía Raman. En consecuencia, los pigmentos que conforman la paleta pictórica de esta obra de arte, como los óxidos de hierro y el negro de humo, han podido ser confirmados mediante la complementariedad de ambas técnicas. Adicionalmente, el sustrato estructural y la naturaleza química de los dispersantes/imprimadores de los colorantes fueron caracterizados, obteniéndose evidencias de la presencia de sílice y aluminosilicatos combinados tanto con los óxidos de hierro como con el negro de humo.

Palabras clave: pigmentos; escultura clásica; policromía; dispersantes; mármol; espectroscopía Raman; ESEM-EDX.

\section{Introduction ${ }^{1}$}

The monochromatic appearance of ancient sculpture gave rise to new and modern canons of sculpture characterised by an emphasis on form with little consideration of colour. In antiquity, however, Greek and Roman sculptures were originally richly embellished with colourful painting, gilding, silvering, and inlay. Roman artists used a wide range of pigments, painting media, and surface applications to embellish their marble sculptures (Abbe, 2015: 173-188; 2020: 1-21; Bradley, 2009). Such polychromy has mostly been lost in burial and survives today only in fragmentary condition.

Therefore, it is possible to affirm that the application of coloured primings was customary in ancient marble sculptures, generally as a means to highlight faces, clothing, and jewels. In other cases, the elimination of irregularities of the surface, especially in limestone or sandstone, could have been achieved (Abbe, 2015: 173-188; 2020: 1-21; Bradley, 2009). Unfortunately, for diverse reasons, it has not come to our days. Several factors, such as fragility, the original conditions of the location and burial, and the change of aesthetic taste, have prevented these ancient sculptures from being observed as they were devised. This circumstance has led to the false belief that antique sculptures were white as the marble.

1 The first three authors of this paper are members of Archaeological and Historical Materials (АНМАт) Research Group and GdS-Optronlab Research Group.
Several studies have been carried out, trying to add to the insufficient knowledge about the original polychromy of ancient sculptures (Noguera, 2002: 373-412; Østergaard, 2009: 68-73; Verri et al., 2010: 39-54; Burón et al., 2016: 209-216; Liverani, 2016: 107-124; Cosano et al., 2017: 191-197; Ganetsos et al., 2019: 51-61; Campbell, 2020b: 175-201). One of the most wide-ranging studies on the subject has been performed by the $\mathrm{Ny}$ Carlsberg Glyptotek (Østergaard, 2009: 68-73). Since 2004, the Ny Carlsberg Glyptotek and the Copenhagen Polychromy Network - CPN- carried out a project on several sculptures of their collections. The studied sculptures were chosen following two criteria: the presence of traces of ancient polychromy and the potential for throwing light on sculptural polychromy in poorly documented periods -namely, Classical and Hellenistic Greek-. From the reported results, it follows that only natural pigments produced according to ancient recipes were used in the sculptures fabricated in those periods. The outcome of these activities was published in successive reports, which are accessible online (http://www. trackingcolour.com/; Østergaard, 2009: 68-73).

One of the better suited experimental techniques for ancient pigments identification and non-destructive study of archaeological or cultural heritage samples, is Raman spectroscopy (Bersani and Lottici, 2016: 499-530; Pinto et al., 2020: 1-16). In particular, Raman spectroscopy has been previously applied to study the colouring of different artworks from ancient Rome, such as pottery, mosaics, and wall paintings (Boschetti et al., 2008: 1085-1090;

Zephyrus, LXXXVIII, julio-diciembre 2021, 193-207 


\section{from a Togatus Roman Sculpture found in Salamanca}

Edwards et al., 2009: 553-560; De Benedetto et al., 2011: 1317-1323). It has also been used to identify the pictorial material in coloured statues (Østergaard, 2009: 68-73; Verri et al., 2010: 39-54; Cosano et al., 2017: 191-197; Campbell, 2020b: 175-201). For example, Cosano et al. (2017: 191-197) studied the polychromy remains of three seated Roman statues found on the Torreparedones archaeological site, in Baena, Jaén. The results obtained by Raman spectroscopy identified the use of goethite as a yellow pigment, ochre red or red earth as red pigment, and Egyptian blue as a blue pigment. Campbell (2020b: 175-201) also applied Raman spectroscopy in the study of the Antonine Wall Distance Sculptures. In this case, the use of Raman spectroscopy was complemented by non-destructive elemental composition determination by X-ray fluorescence (XRF). The combination of both techniques provided evidence of the use of pigments such as vermillion, bright-red minium (red lead), yellow ochre, or lead white (Campbell, 2020b: 175-201). The joint potential of Raman spectroscopy and techniques for elemental composition determination -such as XRF or environmental scanning electron microscopy (ESEM) with an energy-dispersive X-ray analyser (ESEM-EDX)- has prompted the design of hyphenated systems. However, combining both kinds of analytical techniques in a single apparatus presents noticeable difficulties (Cardell and Guerra, 2016: 156-166).

The object of the present work is to apply this combined approach to analysing the pigmentation of a marble statue unearthed in the course of an archaeological intervention in the city of Salamanca, Spain, at the end of 2015 (Jiménez and Rupidera, 2016: 139-165; Salinas et al., 2016: 553-576). The excavated plot where the statue was found is located at a privileged emplacement within the ancient Roman city, close to the probable intersection of the axes that structured the village -i.e., kardo and decumanus- (Fig. 1). More specifically, the plot is placed along the kardo, which is supposed to have been the urban section of the Roman road between Emerita and Asturicam -i.e., 'Via de la Plata'(Jiménez and Rupidera, 2016: 139-165).
Two large fragments of the statue were recovered, which permitted to identify it as a togatus -figure with a Roman robe or toga-. It must have certainly been an exponent of the official statuary that would be installed in some building or public space of the former Salmantica forum, most probably forming part of a customary pre-established program. The sculpture was reworked and used as construction material at an indeterminate time and discarded later, remaining as simple filling until its discovery.

The preservation of the two fragments, which correspond to the right side -smaller fragment- and a part of the body -larger fragment- of the figure, was very poor. However, the fracture planes of both fragments presented a good state of conservation, allowing for their correct union. At the time of the discovery, and during its transfer to the restoration laboratory of the Museum of Salamanca, the sculpture was covered by earthy concretions of significant volume, which were compacted and highly adhered to its surface. This fact hid some folds of the tunic carved into the marble. This type of alteration was particularly relevant in the smaller fragment. The numerous impacts and losses on the original surface revealed the characteristics of the marble -type of grain, colour, etc.-. As mentioned before, as a consequence of its re-use in later times, most of the folds of the robe had been removed, and only those located in the upper part of the figure were preserved. Notwithstanding the preservation state, due to the type of marble, the formal characteristics, and the archaeological context of the area where it was unearthed, the statue could be dated with certainty in the period of the High Roman Empire ruled by the Julio-Claudian dynasty. This finding was of significant relevance, as it was the first togatus statue found in this archaeological site. Furthermore, it provided remarkable evidence for the study of the historical evolution of Salamanca, and it highlighted the relevance of the ancient Salmantica on the Lusitanian territory (Jiménez and Rupidera, 2016: 139-165).

Visual inspection of both fragments revealed different coloured spots: reddish, grey, and black tonalities, the latter mainly located in the frontal part of the 


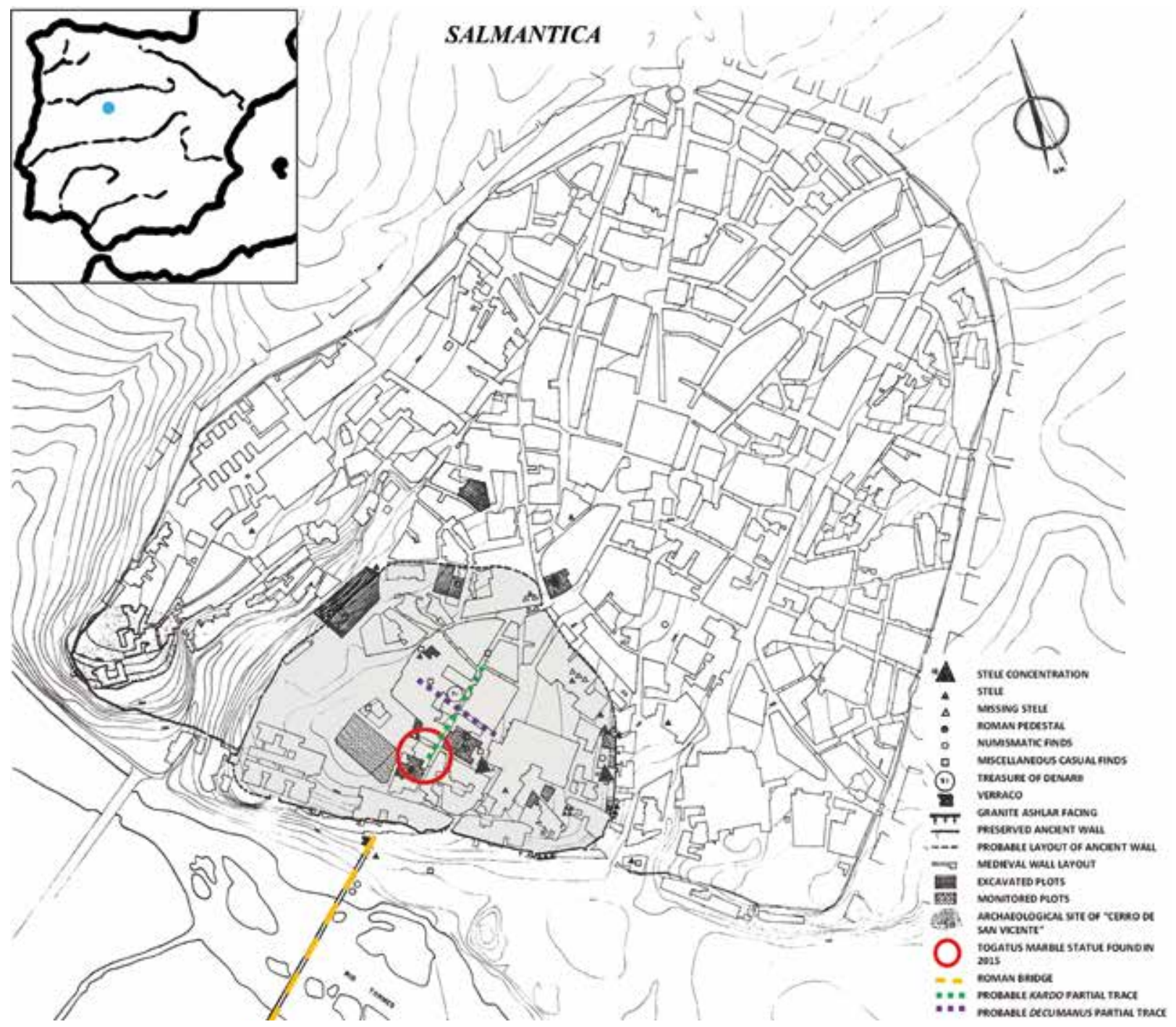

FIG. 1. Map of Salamanca (Spain) showing the ancient wall, which followed itself the layout of the Roman wall, and representative archaeological landmarks of the city. The inset shows the location of Salamanca on the Iberian Peninsula map. The excavation plot where the togatus was found is indicated with a red circle, placed in the nucleus of ancient Salmantica (adapted from Martin Valls et al., 1991: 138, fig. 1).

chest. Herein, the identification by Raman spectrosCopy and ESEM-EDX of the pigments employed on the polychromy of this togatus statue is presented.

\section{Methodology}

The studied sculpture is currently located in the Museum of Salamanca, Spain, and catalogued as piece 556 (Fig. 2a). Additional details about the statue, its discovery, and archaeological context can be found elsewhere (Jiménez and Rupidera, 2016: 139-165; Salinas et al., 2016: 553-576). As mentioned, most of the polychromy of the sample is lost; however, a few coloured spots on the surface of well-preserved carved folds of the tunic could still be identified. Three stratigraphic samples obtained 

from a Togatus Roman Sculpture found in Salamanca
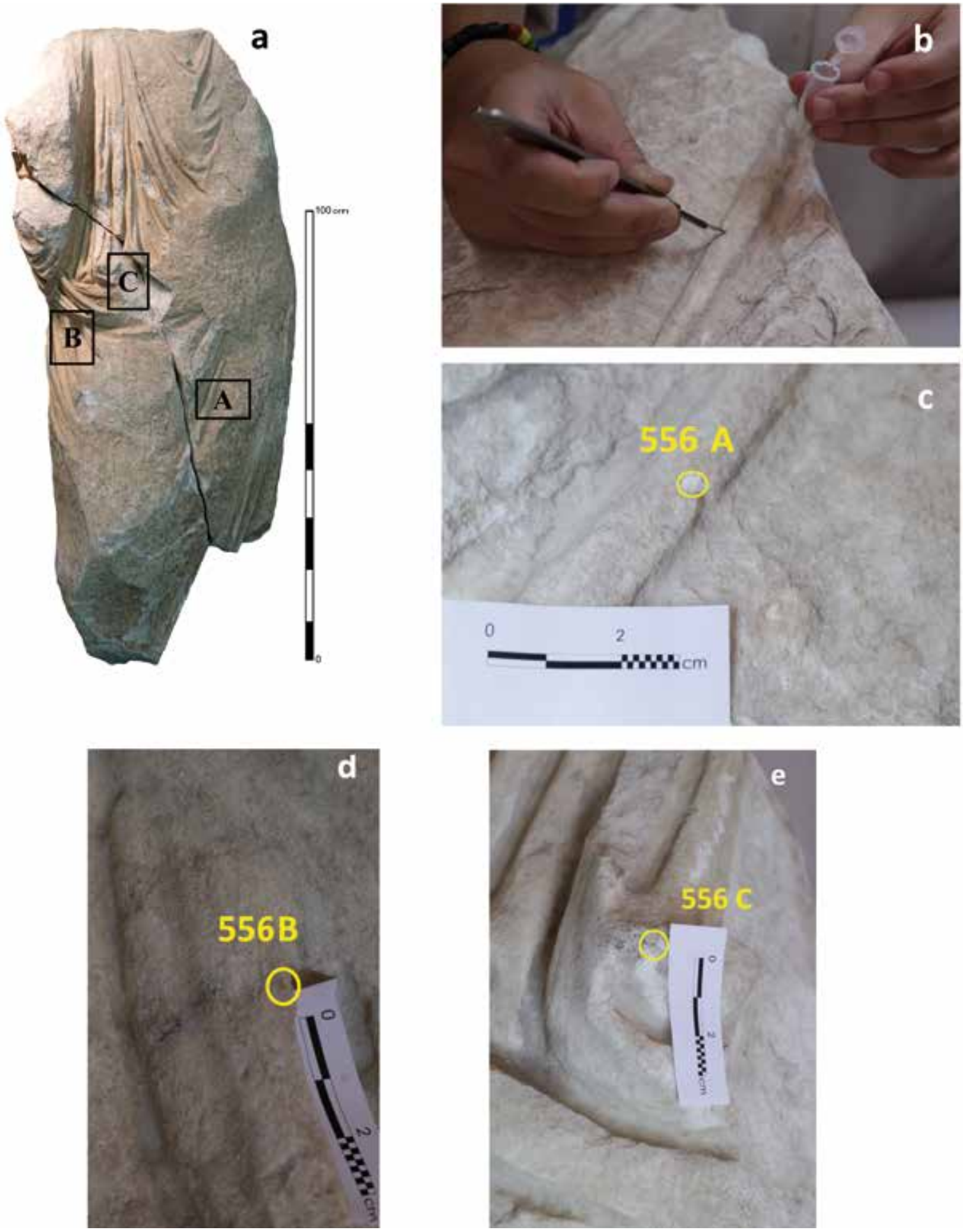

Fig. 2. a) Two fragments of the sculpture after being assembled, as displayed at the Museum of Salamanca; the dotted rectangles indicate the areas from which each stratigraphic sample was collected; $b$ ) Detail of the mechanical sample collection; $c$ ) Detail of sample 556A; d) Detail of sample 556B; e) Detail of sample 556C. 
by mechanical means from the sculpture (Fig. 2b) have been studied in this work. These samples were selected to be representative of the reddish, grey, and black remains of the original polychromy of the statue (556A to 556c; see Fig. 2).

The electron microscopy study was performed with an FEI Quanta 200FEg environmental scanning electron microscope. It is equipped with Everhardt-Thornley -high vacuum-, large field -low vacuum-, secondary electron -ESEM mode-, backscattering electron diffraction -high and low vacuum-, and EDX detectors. The EDX microanalyser, a Genesis xm2i model, allows for the observation and analysis of wet samples at ambient pressures without the need for superficial metallisation. The Genesis хм2i identifies light elements effectively from boron (в) with resolution $<135 \mathrm{eV}$. A Peltier stage permits working with humid samples and environments.

A high-resolution Horiba-Jobin Yvon Labram HR 800 uv Raman spectrometer, with an Olympus Bx41 microscope and a Symphony CCD detector, was used for the acquisition of Raman spectra -microscopic backscattering mode with x100 magnification-. The $\lambda=532.8 \mathrm{~nm}$ line from a solid-state laser was used as the excitation beam. The nominal laser power on the sample is $1 \mathrm{~mW}$, with an approximate irradiance of $100 \mathrm{~kW} \cdot \mathrm{cm}^{-2}$. The acquisition time was set at $120 \mathrm{~s}$, and spectral slit aperture at $300 \mu \mathrm{m}$, achieving a spectral resolution better than $1 \mathrm{~cm}^{-1}$. Before the measurements, the equipment was calibrated with the $v(\mathrm{Si}-\mathrm{Si})$ mode at $520.7 \mathrm{~cm}^{-1}$.

\section{Results and discussion}

\subsection{Sample 556A}

The stratigraphic sample 556A presented remains of red hues. An ESEM image -x10000 magnification- of a region close to the surface of the 556A stratigraphic sample is shown in Fig. 3a. It was possible to differentiate two regions: a heterogeneous -top- region corresponding to the surface of the sculpture; and a homogeneous -bottom- region

Ediciones Universidad de Salamanca / @ه্త corresponding to the material from which the statue was fabricated (Fig. 3a). Four representative areas of the sample were selected to study their composition (Fig. 3a). The ESEM-EDX spectra obtained on these four zones of the specimen are shown in Fig. 3b. $\mathrm{Ca}, \mathrm{C}$, and $\mathrm{O}$ are the major elements in the calcareous substrate -point $1-$. This result confirms that the sculpture was made from a block of marble with very high calcite $\left(\mathrm{CaCO}_{3}\right)$ content. The EDX analysis of the heterogeneous surface shows relevant Fe contents in point 2, probably associated with the chromophore material, while aluminosilicates can be clearly identified in point 3 -although they are also observed at a lower concentration in point 2-. Dispersed particles with significant contents of $\mathrm{Ti}$, probably due to the presence of anatase or rutile $\left(\mathrm{TiO}_{2}\right)$, are evident in the EDX spectrum from point 4.

The Raman spectrum in Figure 3.c corresponds to a zone with red pigmentation. Characteristic vibrational modes of hematite $\left(\alpha-\mathrm{Fe}_{2} \mathrm{O}_{3}\right)$ are identified at 220 and $500 \mathrm{~cm}^{-1}\left(\mathrm{~A}_{1 \mathrm{~g}} \mathrm{Fe}-\mathrm{O}\right.$ symmetric stretching) and at 287, 404 and $610 \mathrm{~cm}^{-1}-\mathrm{E}_{\mathrm{g}}$ Fe-O symmetric bending- (De Faria et al., 1997: 873-878; De Faria and Lopes, 2007: 117-121; Hanesch, 2009: 941-948). Additionally, spectral features that correspond to magnetite $\left(\mathrm{Fe}_{3} \mathrm{O}_{4}\right)$ are observed at $660 \mathrm{~cm}^{-1}-\mathrm{A}_{1 \mathrm{~g}} \mathrm{Fe}-\mathrm{O}$ symmetric stretching- and $325 \mathrm{~cm}^{-1}$-shoulder, $\mathrm{E}_{\mathrm{g}} \mathrm{Fe}-\mathrm{O}$ symmetric bending- (Shebanova and Lazor, 2003a: 424-430; 2003b: 845-852). It should be noticed that the $\mathrm{T}_{2 \mathrm{~g}}$ $\mathrm{Fe}-\mathrm{O}$ asymmetric bending mode of magnetite that should be observed at about $520 \mathrm{~cm}^{-1}$ overlaps with the hematite mode at $500 \mathrm{~cm}^{-1}$. The simultaneous presence of these two kinds of iron oxides is not to be unexpected, as they are usually mixed in nature (Cosano et al., 2017: 191-197).

Accordingly, the red hues of the sculpture were obtained using hematite, in good agreement with previous results on Raman sculptures (Verri et al., 2010: 39-54; Cosano et al., 2017). On the other side, the presence of anatase or rutile particles is probably related to occasional occurrence in the materials employed, as there is no evidence of its intended use as a pigment at ancient times (Baraldi

Zephyrus, LXXXVIII, julio-diciembre 2021, 193-207 

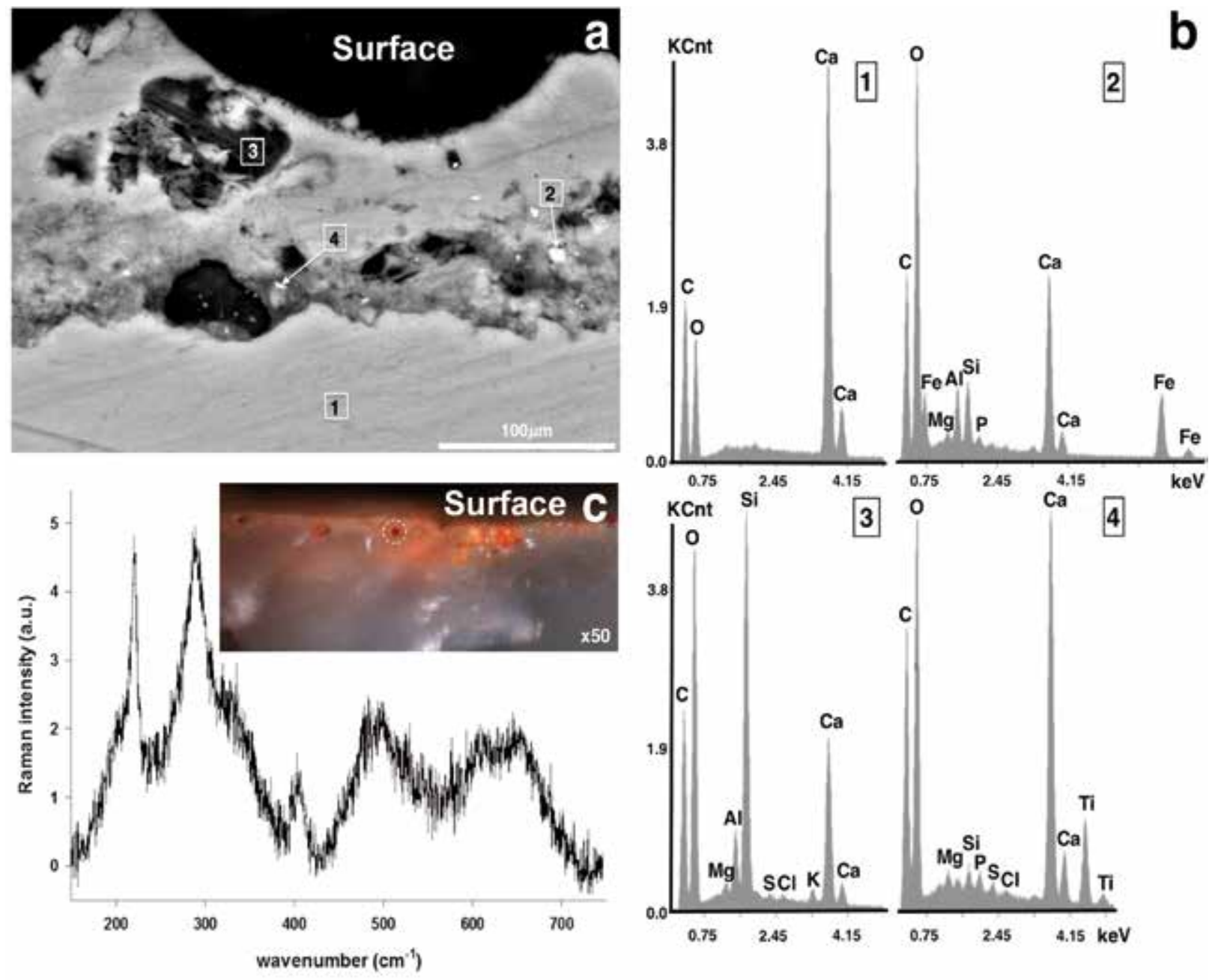

FIG. 3. Stratigraphy 556A: a) SEM micrograph; b) EDX analysis obtained from the regions marked 1-4 on the micrograph; c) Raman spectrum from red pigmentation, as identified by the circle in the photograph of the stratigraphy (upper red layer and white stratum correspond to the pictorial coating on the surface of the statue and the marble substrate, respectively).

et al., 2007: 420-426; Howell, 2015; Jorge-Villar et al., 2018: 1207-1223).

Moreover, the presence of phosphorus (P) in points 2 and 4, close to the marble substrate, could indicate the use of bone as preparation or fixing base, binder, or white pigment combined with the red pigments to give the desired red hue (Beltrán et al., 2018: 275-287). In fact, the use of bone white to lighten the red colour of hematite has been previously reported in a seated state found in the Torreparedones Roman archaeological site, in Baena, Spain (Cosano et al., 2017:
191-197). However, the Raman spectra from this stratigraphy have not evidenced the presence of calcium phosphate. Therefore, its presence cannot be firmly stablished.

\subsection{Sample $556 B$}

As was the case for sample 556A, stratigraphic sample 556B consists of the sculptural marble substrate and red hues on the surface. A micrograph, as well as maps illustrating the semiquantitative elemental chemical distribution for the stratigraphic 
specimen 556B, are shown in Fig. 4a. In more detail, Fig. $4 \mathrm{~b}$ depicts the relative elemental composition profiles along a line starting at the marble substrate and ending at the surface -i.e., pictorial layer- of the stratigraphy. The results evidence the differences between the marble substrate, which is clearly identified by the majority distribution of $\mathrm{Ca}$, and the external pictorial layer. The pictorial stratum is characterized by a homogenous presence of $\mathrm{Si}, \mathrm{Al}, \mathrm{K}, \mathrm{Fe}$, and $\mathrm{O}$. Fe and $\mathrm{O}$ are expected to be related to the use of iron oxides as red pigments, as previously identified in sample 556A. This hypothesis is confirmed by the Raman spectroscopy results.
The Raman spectrum of a red area on the outermost stratum in specimen 556в is denoted as (2) in Fig. 4c. The spectral features are very similar to those already described for sample 556A. In addition to the bands previously correlated to the $\mathrm{Ra}$ man spectra of $\alpha-\mathrm{Fe}_{2} \mathrm{O}_{3}$ and $\mathrm{Fe}_{3} \mathrm{O}_{4}$, a strong peak is observed at $466 \mathrm{~cm}^{-1}$. This peak corresponds to an $\mathrm{A}_{1}$ symmetry vibration of $\alpha$-quartz $\left(\mathrm{SiO}_{2}\right)$ (Krishnamurti, 1958: 276-277; Scott and Porto, 1967: 903-910) this assignment being further supported by the presence of two additional bands at 128 -weak-and 206-shoulder- $\mathrm{cm}^{-1}$, that can be respectively attributed to $\mathrm{E}$ and $\mathrm{A}_{1}$ symmetry vibrational

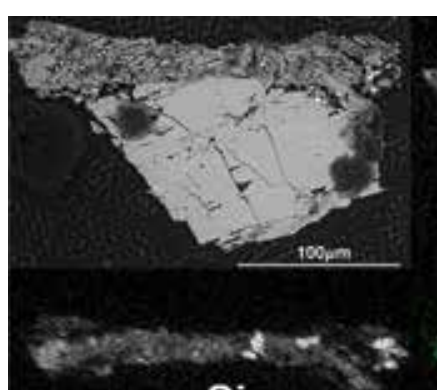

Si

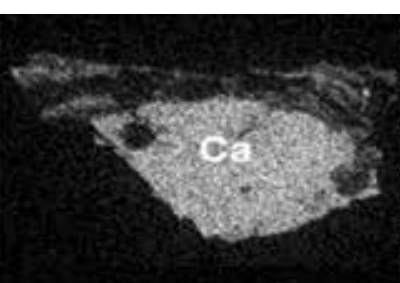

ह

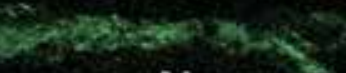

Al

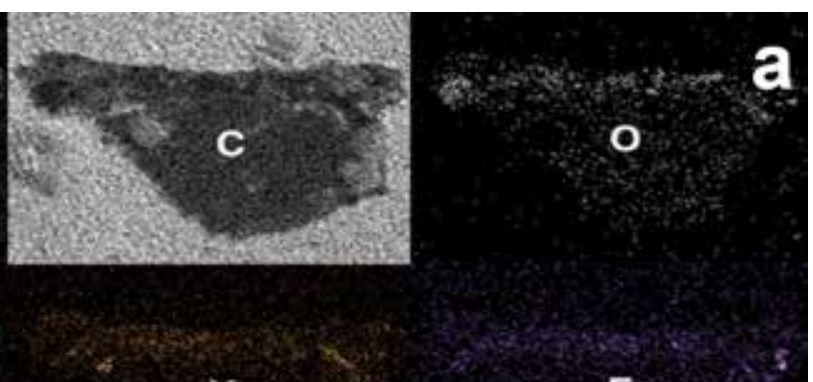

K
$\mathrm{Fe}$
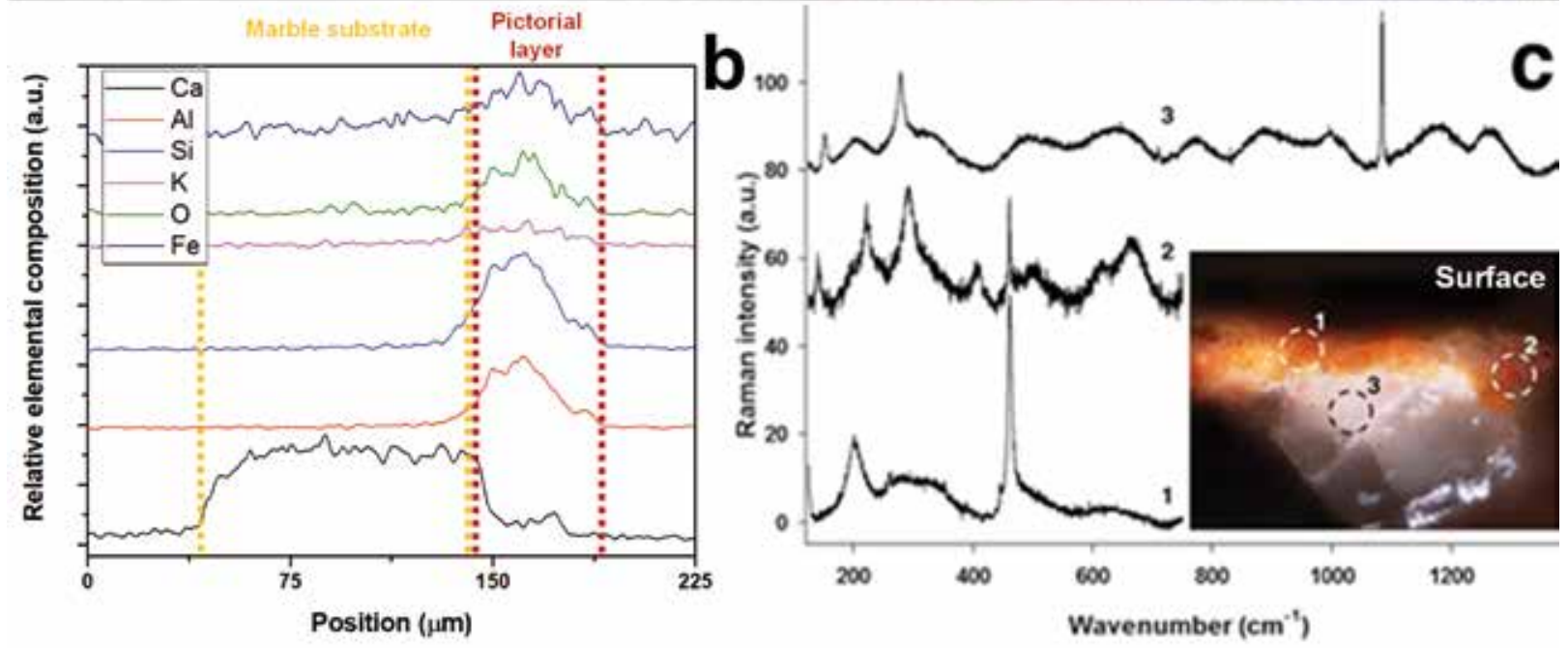

FIG. 4. Stratigraphy 556B: a) SEM micrograph (top left) and elemental chemical distribution maps; b) Relative elemental composition profiles evidencing the diverse composition of the substrate and pictorial layer; c) Raman spectra from two coloured spots on the surface (1 and 2) and from the calcareous substrate (3) identified by the circles in the photograph of the stratigraphy (upper red and lower white regions correspond to the pictorial layer on the surface of the statue and the marble substrate, respectively). 

from a Togatus Roman Sculpture found in Salamanca

modes of $\alpha$-quartz (Krishnamurti, 1958: 276-277; Scott and Porto, 1967: 903-910). These results are entirely consistent with those obtained from the elemental analysis and indicate that quartz could have been used as a dispersant for the red pigment. The mixing of small amounts of silica with hematite
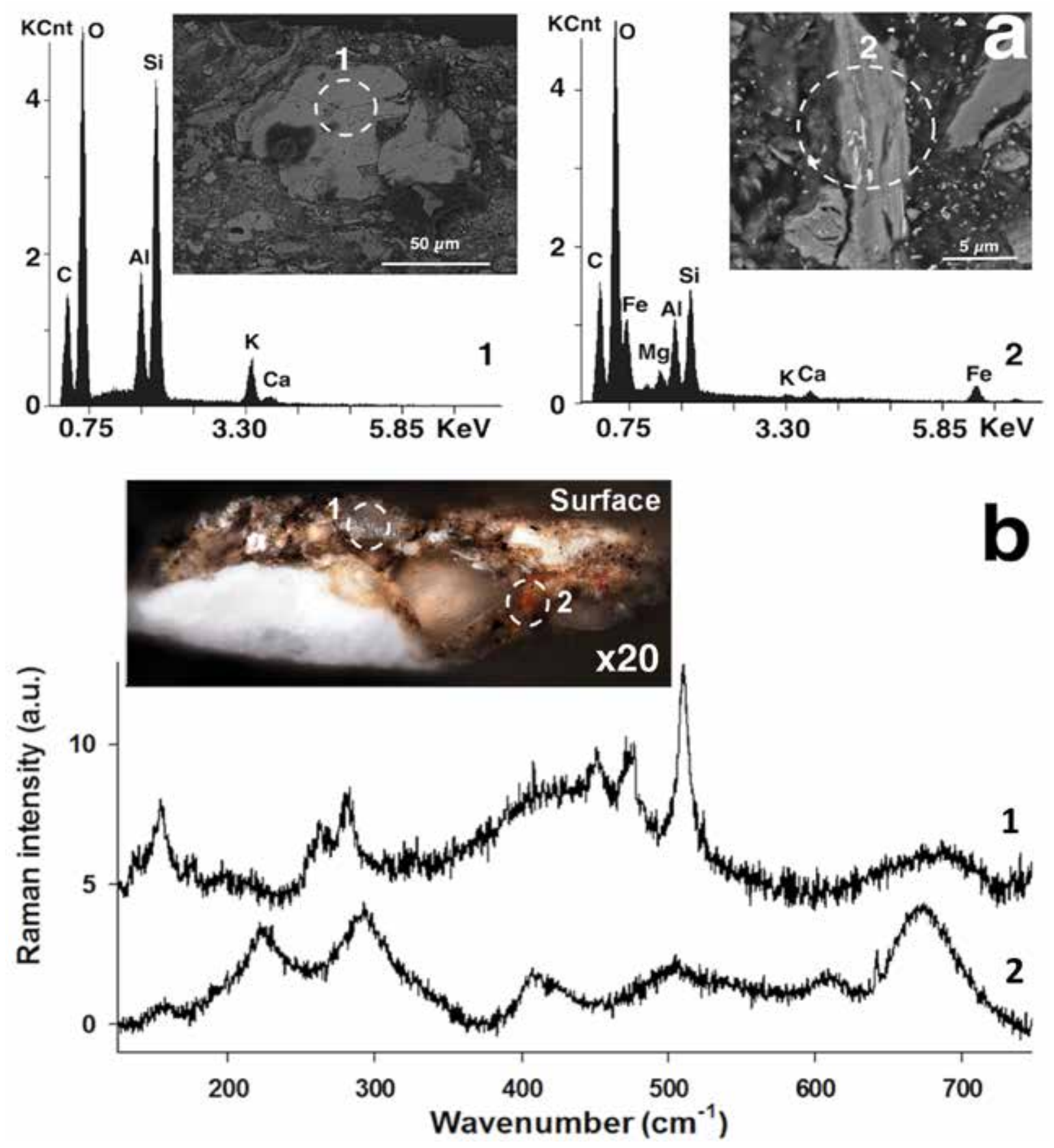

FIG. 5. Stratigraphy 556C: a) SEM micrographs and EDX spectra from grey (1) and red (2) spots; b) Raman spectra from grey (1) and red (2) regions, identified by the circles in the photograph of the stratigraphy (upper layer and white stratum correspond to the pictorial coating in the surface of the statue and the marble substrate, respectively). 
for the so-called 'red earth' or 'ochre red' pigments is a common finding in pictorial materials of ancient times (Clark and Gibbs, 1997: 99-103; Cosano et al., 2017: 191-197). On certain spots of this specimen, the Raman spectrum was primarily dominated by the $\alpha$-quartz modes, as illustrated in the spectrum marked as (1).

The Raman spectrum of the calcareous substrate is also shown in Fig. 4c, trace (3). It corresponds to a characteristic spectrum of calcite $\left(\mathrm{CaCO}_{3}\right)$, with a strong peak located at $1086 \mathrm{~cm}^{-1}$, a band of medium intensity at $282 \mathrm{~cm}^{-1}$ a weak band at $154 \mathrm{~cm}^{-1}$, and a very weak band at $714 \mathrm{~cm}^{-1}$. The strongest band corresponds to the $\mathrm{CO}_{3} v_{1}$ symmetric stretching of $A_{1 g}$ symmetry, while the weakest is the $\mathrm{CO}_{3} v_{4}$ symmetric deformation, of $\mathrm{E}_{\mathrm{g}}$ symmetry. The other two are due to in-phase libration modes of the carbonate ion $\mathrm{T}\left(\mathrm{Ca}, \mathrm{CO}_{3}\right)$ of $\mathrm{E}_{\mathrm{g}}$ symmetry (Gunasekaran et al., 2006: 892-899; De La Pierre et al., 2014).

The results obtained by Raman spectroscopy confirmed the use of hematite and magnetite as red pigments and the presence of quartz as a dispersant. However, the notable concentration of $\mathrm{Al}, \mathrm{Si}$, and $\mathrm{K}$ derived from EDX also indicates that aluminosilicates are present in the pictorial stratum. It should be noticed that aluminosilicates -i.e., clays- are homogeneously dispersed within, and not over, the pigments. Accordingly, the presence of aluminosilicates because of an alteration or pollution of the sculpture can be discarded. Thus, the composition of the pictorial red layer seems compatible with the use of ochre red as pigment -i.e., natural pigment containing iron oxides, silica, and clay- (Franquelo et al., 2009: 404-412).

\subsection{Sample 556C}

Finally, stratigraphic sample 556c presents a higher diversity in terms of colour, displaying grey, red, and black hues. Figure 5a shows ESEM images and EDx spectra of the 556c stratigraphy, as collected from grey (1) and red (2) coloured areas. The grey areas present $\mathrm{O}, \mathrm{Si}, \mathrm{Al}, \mathrm{C}, \mathrm{K}$, and $\mathrm{Ca}$ as major elements. This sequence of the elemental content

Ediciones Universidad de Salamanca / 요 of the stratum is also observed in areas of intense red colour. However, not only a higher relative oxygen concentration is detected in those regions with a red pigmentation, but a significant level of iron (Fe) can also be noticed.

Raman spectra, as recorded from red and grey areas of the stratigraphic specimen, are displayed in Fig. 5b. The spectrum from the red portion (2) corresponds again to a mixture of hematite and magnetite. The relative intensities of the bands seem to indicate that the ferrous-ferric oxide content is higher in this particular spot than in the previously reported regions; as a matter of fact, the $A_{1 \mathrm{~g}}$ magnetite band at $660 \mathrm{~cm}^{-1}$ is the most intense feature in the spectrum, and the $T_{2 g}$ mode can now be identified as a weak band at about $225 \mathrm{~cm}^{-1}$.

The Raman spectrum of the grey area (Figure 5b, [1]) shows bands at $155(\mathrm{~m}), 176(\mathrm{vw}), 262(\mathrm{w})$, $282(\mathrm{~m}), 452(\mathrm{w}), 474(\mathrm{~m}), 511(\mathrm{~s})$ and 686 (w) $\mathrm{cm}^{-1}$. This group of Raman bands is attributable to fundamental modes of vibration of feldspar (Matson et al., 1986; McKeown, 2005: 15061517). Specifically, the bands at 155 and $175 \mathrm{~cm}^{-1}$ correspond to external modes of shear deformation of the lattice structure of $\mathrm{TO}_{4}$ tetrahedra presenting $\mathrm{Si}^{+4}\left(\mathrm{Al}^{+3}\right)$ substitutions in the tetrahedral $(\mathrm{T})$ positions. The bands at 262 and $282 \mathrm{~cm}^{-1}$ correspond to external libration (roto-translation) modes of the aforementioned network structures. The three bands at 452,474 , and $511 \mathrm{~cm}^{-1}$ are due to the internal $\delta$ (T-O-T), (T: Si, Al) angular deformation modes, while the broad band centred at $686 \mathrm{~cm}^{-1}$ can be assigned to the $v(\mathrm{TO})$ stretching in the tetrahedra of the aluminium tectosilicates of the feldspar group. The positions of the bands and the relative Raman intensity pattern permits to determine that the silicates consist of ternary feldspar (microcline phase) composed of orthoclase $\left(\mathrm{KAlSi}_{3} \mathrm{O}_{8}\right)$, albite $\left(\mathrm{NaAlSi}_{3} \mathrm{O}_{8}\right)$, and anorthite $\left(\mathrm{CaAl}_{2} \mathrm{Si}_{2} \mathrm{O}_{8}\right)$, with potassium aluminium silicate as the preponderant and majority phase (Freeman et al., 2008: 1477-1500). These results obtained by Raman spectroscopy confirm the previous observations that suggested the presence of aluminosilicates in the pictorial layer.

Zephyrus, LXXXVIII, julio-diciembre 2021, 193-207 
EsEm images and EDX spectra from two black-coloured areas of stratigraphy 556c are shown in Figure 6a. The main elements in both black areas are $\mathrm{C}, \mathrm{O}, \mathrm{Si}$, and $\mathrm{Al}$, with lower concentrations of $\mathrm{K}$, $\mathrm{Ca}, \mathrm{Mg}$, and $\mathrm{Na}$. The high carbon content, which is particularly relevant in (2), suggests that the dark pigmentation comes from unorganised organic matter-soot or carbon black-. At the same time, aluminosilicate phases could correspond again to the primers for the organic matter. It should be noticed that the analysed black areas were selected close to the marble substrate, aiming to avoid possible external alterations of the pictorial stratum. Moreover, the presence in nearby areas of organic matter combined with aluminosilicates -black spots- and iron oxides combined with aluminosilicates -red spots- suggests an intentional application of the aluminosilicates.

The Raman spectrum, as collected from a black area, is shown in Fig. 6b. The presence of poorly organised carbonaceous materials is supported by a broad band $\left(\mathrm{D}_{1}\right)$ located in the first-order Raman spectrum at around $1370 \mathrm{~cm}^{-1}$. This band is assigned to vibrations of $\mathrm{C}-\mathrm{C}$ bonds with species of symmetry $A_{1 g}$ in disordered graphite. The $\mathrm{G}$ band, characteristic of the $\mathrm{sp}^{2}$ hybridisation of the graphite, is centred at $1580 \mathrm{~cm}^{-1}$. It corresponds to the $\mathrm{E}_{2 \mathrm{~g}}$ symmetric C-C stretching in aromatic structures. Two additional modes that overlap with the $\mathrm{G}$ band can be identified at approximately 1620 and $1520 \mathrm{~cm}^{-1}$. These are assigned to the $\mathrm{D}_{3}$ and $\mathrm{D}_{2}$ bands in disordered or amorphous carbon (Sadezky et al., 2005: 1731-1742; Jehlička et al., 2009: 404-409). These results confirm the presence of carbon black as black pigment on the togatus statue, in good agreement with previous results obtained in Roman sculptures (Campbell, 2020a: 96-109). Nevertheless, it should be noticed that the use of carbon black as a pigment in Roman sculptures has not been usually reported in the tunic of togatus sculptures. However, it was a standard pigment in Roman times (Fostiridou et al., 2016: 453-464; Campbell, 2020a: 96-109).

\subsection{Discussion}

The study of the polychromy remains and features of a Roman togatus may yield relevant information for the interpretation of the status of the character represented -e.g., toga praetexta or triumphal toga picta in the Richmond Caligula- (Brøns and Skovmøller, 2017; Ostergaard, 2020: 50-54). Moreover, the identification of the pigment remains and their distribution on the sculpture have been used to provide estimated reconstructions of the original polychromy -e.g., the coloured clavus proposed for the togatus found in Osuna, Sevilla in 1950- (Beltrán et al., 2018: 275-287). However, the poor preservation state of the fragments of the togatus found in Salamanca, with just a few remaining folds, hinders a detailed interpretation of the tunic features or the estimation of the colour distribution on the sculpture.

The obtained results indicate the use of ochre red -i.e., iron oxides- as red pigment, in good agreement with previous works addressing the polychromy of Roman sculptures ${ }^{2}$. In particular, the presence of iron oxides as pigments has been suggested in the tunic of the togatus found in Osuna, Sevilla (Beltrán et al., 2018: 275-287) or the toga of the statue of the freedman Gaius Fundilius Doctus -Sanctuary of Diana Nemorensis in Nemi, Italy (Brøns and Harlow, 2020: 219-240)-.

Moreover, the use of carbon black as a pigment in the tunic is also proposed. This pigment has been previously found in the hair -e.g. Treu Head- or the skin -e.g., Statue of Mars, York- of Roman sculptures, but it has not been previously reported for the tunics (Verri et al., 2010: 39-54; Campbell, 2020a: 96-109). Unfortunately, the scarce polychromy remains of the togatus found in Salamanca are not enough to ensure the intentional use of this pigment. However, its presence close to the marble substrate, presenting a dispersion within silica and aluminosilicates similar to that detected for iron oxides, suggests its use as a pigment. It should be

2 Skovmøller, A.: Portraits and Colour-codes in ancient Rome: The Polychromy of white marble Portraits. $\mathrm{PhD}$ thesis presented in 2016 at the University of Copenhagen.

Zephyrus, LXXXVIII, julio-diciembre 2021, 193-207 

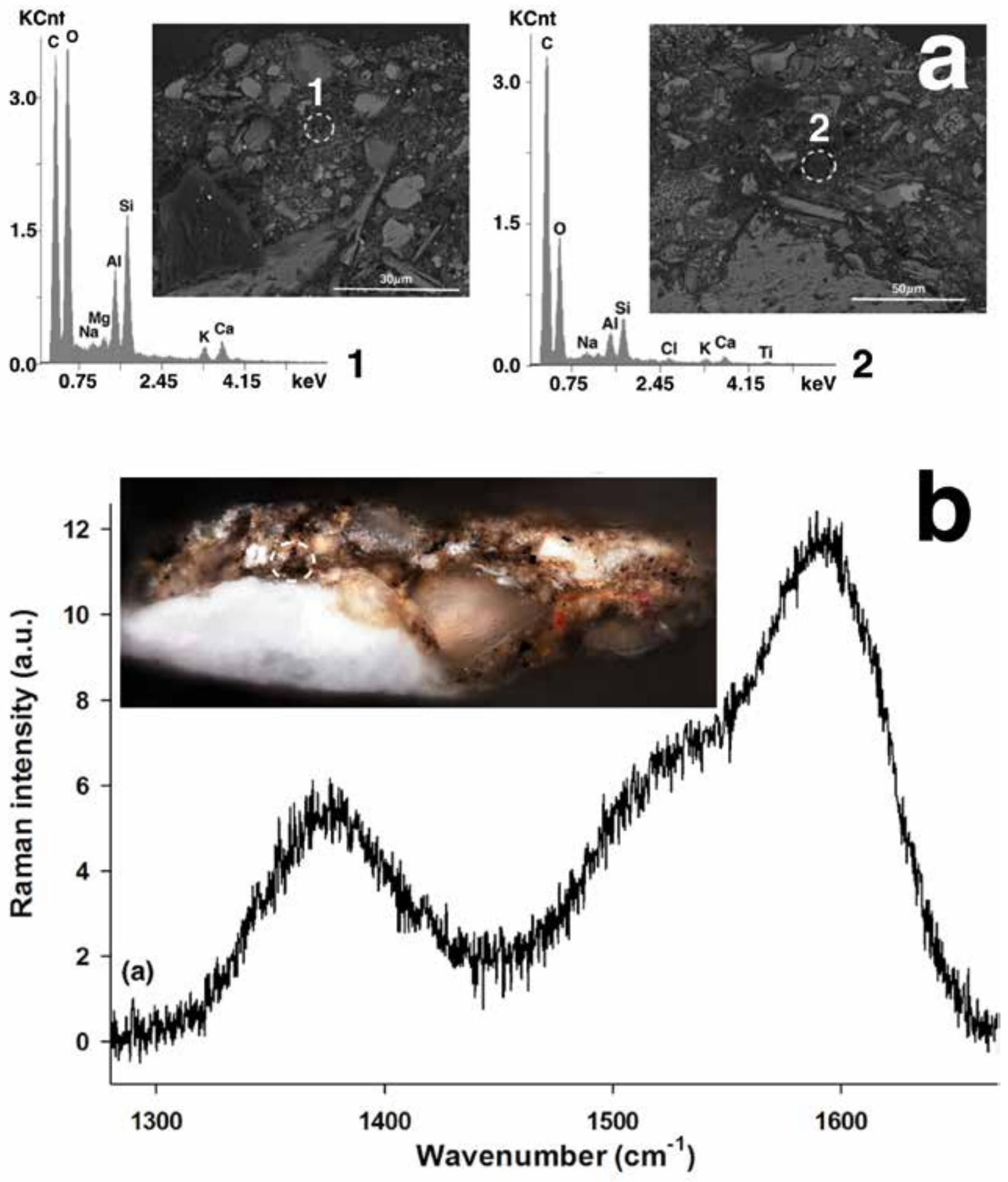

FIG. 6. Stratigraphy 556C: a) SEM micrographs and EDX spectra from two black (1-2) spots; b) Raman spectra from black pigment, obtained in the area indicated with a white circle in the photograph of the stratigraphy. 
noticed that the presence of carbon black was confirmed close to iron oxides in the bottom part of a fold (Fig. 2e). Thus, it could have been employed to produce shadow effects, accentuating the sculpted form (Brøns and Skovmøller, 2017).

In addition, it is known that ochre red and carbon black pigments are particularly persistent due to their chemical stability, fine grain, and to the fact that they are usually embedded in the marble surface (Claridge, 2011) ${ }^{3}$. Therefore, it cannot be discarded that these pigments were employed as an undercoat, possibly being the penultimate phase of the process prior to the addition of the real colour (Claridge, 2011), or underdrawings ${ }^{4}$.

\section{Conclusions}

ESEM-EDX and Raman spectroscopy in microscopic mode have been used as analytical tools to study the pigments used in a togatus Roman sculpture found in Salamanca (Spain) in 2015. These complementary techniques have permitted the identification of the components of the pictorial layer and confirmed the marbled nature of the statue body. The material used for the red tones consists of a natural combination of iron oxides -hematite and magnetite- mixed with silica and aluminosilicates -i.e., ochre red-. Soot or carbon black seem to have been used in the black areas, also combined with silica and aluminosilicates.

\section{Bibliography}

Abbe, M. (2015): "Polychromy". In Friedland, E. A.; Sobocinski, M. G. and Gazda, E. K. (eds.): The Oxford handbook of Roman sculpture. Oxford: oup, pp. 173-188. https://doi.org/10.1093/oxford$\mathrm{hb} / 9780199921829.013 .0012$

Авве, M. (2020): "Politura and Polychromy on Ancient Marble Sculpture”, CLARA: Classical Art and Archaeology, 1, pp. 1-21.

3 Also Skovmøller, op. cit. n. 1.

4 Also Skovmøller, op. cit. n. 1.
Baraldi, P.; Baraldi, C.; Curina, R.; Tassi, L. and ZANNINI, P. (2007): "A micro-Raman archaeometric approach to Roman wall paintings", Vibrational Spectroscopy, 43 (2), pp. 420-426. https://doi. org/10.1016/j.vibspec.2006.04.029

Beltrán, J.; Loza, M. L.; Odriozola, C.; Santos, J. M. and Beladiez, R. (2018): "Análisis de la policromía de un togado romano de Osuna (Sevilla)". In Beltrán, J.; Loza, M. L. and Ontiveros-OrTEGA, E. (eds.): Marmora Baeticae: Uso de materiales pétreos en la Bética romana. Estudios arqueológicos y análisis arqueométricos. Sevilla: Univ. de Sevilla, pp. 275-287.

Bersani, D. and Lottici, P. P. (2016): "Raman spectroscopy of minerals and mineral pigments in archaeometry", Journal of Raman Spectroscopy, 47 (5), pp. 499-530. https://doi.org/10.1002/jrs.4914

Boschetti, C.; Corradi, A. and Baraldi, P. (2008): "Raman characterization of painted mortar in Republican Roman mosaics", Journal of Raman Spectroscopy, 39 (April), pp. 1085-1090. https://doi. org/10.1002/jrs. 1970

Bradley, M. (2009): Colour and Meaning in Ancient Rome. Cambridge: cur.

Brøns, C. and Harlow, M. (2020): "White men and rainbow women: gendered colour coding in roman dress". In Harlow, M.; Michel, C. and Quillien, L. (eds.): Textiles and Gender in Antiquity: From the Orient to the Mediterranean. London: Bloomsbury Academic, pp. 219-240.

Brøns, C. and Skovmøller, A. (2017): "Colour-Coding the Roman Toga", Antike Kunst, 60, pp. 55-79. https://www.jstor.org/stable/10.2307/26663658

Burón, M.; Barrera, M.; Sánchez, I.; Escudero, C.; Alonso, J. L.; Pérez, P. P. and Navarro, J. V. (2016): "Caracterización y recreación de la policromía de la 'Diosa Fortuna' procedente del Teatro Romano de Clunia (Burgos)". In Márquez, C. and OJeDA, D. (eds.): Actas VIII Reunión de Escultura Romana en Hispania. Córdoba, pp. 209-216.

Campbell, L. (2020a): "Monuments on the margins of Empire: the Antonine Wall sculptures". In The Antonine Wall: Papers in Honour of Prof. L. Keppie. Oxford: Archaeopress, pp. 96-109. https://doi.org/10.1 080/00665983.2007.11770990

Campbell, L. (2020b): "Polychromy on the Antonine Wall Distance Sculptures: Non-destructive Identification of Pigments on Roman Reliefs", Britannia, 51, pp. 175-201. https://doi.org/10.1017/ S0068113X20000124

Zephyrus, LXXXVIII, julio-diciembre 2021, 193-207 
Cardell, C. and Guerra, I. (2016): "An overview of emerging hyphenated SEM-EDX and Raman spectroscopy systems: Applications in life, environmental and materials sciences", TrAC-Trends in Analytical Chemistry, 77, pp. 156-166. https://doi.org/10.1016/j. trac.2015.12.001

Claridge, A. (2011): "Looking for Colour on Greek and Roman Sculpture", Journal of Art Historiography, 5 (1). http://www.claridges.co.uk/

Clark, R. J. H. and Gibbs, P. J. (1997): "Non-destructive in situ study of ancient Egyptian faience by Raman microscopy", Journal of Raman Spectroscopy, 28 (23), pp. 99-103. https://doi.org/10.1002/(sici)10974555(199702)28:2/3<99::aid-jrs75>3.0.co;2-u

Cosano, D.; Mateos, L. D.; Jiménez-Sanchidrián, C. and Ruiz, J. R. (2017): "Identification by Raman microspectroscopy of pigments in seated statues found in the Torreparedones Roman archaeological site (Baena, Spain)", Microchemical Journal, 130, pp. 191-197. https://doi.org/10.1016/j.microc.2016.09.003

De Benedetto, G. E.; Nicolì, S.; Pennetta, A.; Rizzo, D.; Sabbatini, L. and Mangone, A. (2011): "An integrated spectroscopic approach to investigate pigments and engobes on pre-Roman pottery", Journal of Raman Spectroscopy, 42 (6), pp. 1317-1323. https://doi.org/10.1002/jrs.2845

De Faria, D. L. A. and Lopes, F. N. (2007): "Heated goethite and natural hematite: Can Raman spectroscopy be used to differentiate them?", Vibrational Spectroscopy, 45 (2), pp. 117-121. https://doi. org/10.1016/j.vibspec.2007.07.003

De Faria, D. L. A.; Venâncio Silva, S. and De Oliveira, M. T. (1997): "Raman microspectroscopy of some iron oxides and oxyhydroxides", Journal of Raman Spectroscopy, 28 (11), pp. 873878. https://doi.org/10.1002/(sici) 1097-4555(199 711)28:11<873::aid-jrs177>3.3.co;2-2

De la Pierre, M.; Carteret, C.; Maschio, L.; AndrÉ, E.; Orlando, R. and Dovesi, R. (2014): "The Raman spectrum of $\mathrm{CaCO} 3$ polymorphs calcite and aragonite: A combined experimental and computational study", Journal of Chemical Physics, 140 (16). https://doi.org/10.1063/1.4871900

Edwards, H. G. M. (2015): "Historical Pigments: A Survey of Analytical Chemical Archaeometric Usage and Terminology for Forensic Art Analysis". In Encyclopedia of Analytical Chemistry, pp. 1-12. https:// doi.org/10.1002/9780470027318.a9527
Edwards, H. G. M.; Middleton, P. S. and Hargreaves, M. D. (2009): "Romano-British wall paintings: Raman spectroscopic analysis of fragments from two urban sites of early military colonisation", Spectrochimica Acta-Part A: Molecular and Biomolecular Spectroscopy, 73 (3), pp. 553-560. https://doi. org/10.1016/j.saa.2008.10.027

Fostiridou, A.; Karapanagiotis, I.; Vivdenko, S.; Lampakis, D.; Mantzouris, D.; Achilara, L. and Manoudis, P. (2016): "Identification of Pigments in Hellenistic and Roman Funeral Figurines", Archaeometry, 58 (3), pp. 453-464. https://doi. org/10.1111/arcm.12177

Franquelo, M. L.; Durán, A.; Herrera, L. K.; Jiménez de Haro, M. C. and Pérez-Rodríguez, J. L. (2009): "Comparison between micro-Raman and micro-FTIR spectroscopy techniques for the characterization of pigments from Southern Spain Cultural Heritage", Journal of Molecular Structure, 924-926 (c), pp. 404-412. https://doi.org/10.1016/j.molstruc.2008.11.041

Freeman, J. J.; Wang, A.; Kuebler, K. E.; Jolliff, B. L. and Haskin, L. A. (2008): "Characterization of natural feldspars by raman spectroscopy for future planetary exploration", Canadian Mineralogist, 46 (6), pp. 1477-1500. https://doi.org/10.3749/can$\min .46 .6 .1477$

Ganetsos, T.; Regki, A.; Laskaris, N. and LiRitzis, I. (2019): "Spectroscopic study of colour traces in marble sculptures and architectural parts of monuments of archaic period in Delphi, Greece", Mediterranean Archaeology and Archaeometry, 19 (3), pp. 51-61. https://doi.org/10.5281/zenodo.3457526

Gunasekaran, S.; Anbalagan, G. and Pandi, S. (2006): "Raman and infrared spectra of carbonates of calcite structure", Journal of Raman Spectroscopy, 37 (9), pp. 892-899. https://doi.org/10.1002/jrs. 1518

Hanesch, M. (2009): "Raman spectroscopy of iron oxides and (oxy)hydroxides at low laser power and possible applications in environmental magnetic studies", Geophysical Journal International, 177 (3), pp. 941-948. https://doi.org/10.1111/j.1365246X.2009.04122.x

JehličKa, J.; ŠŤAstnÁ, A. and Přikryl, R. (2009): “Raman spectral characterization of dispersed carbonaceous matter in decorative crystalline limestones", Spectrochimica Acta-Part A: Molecular and Biomolecular Spectroscopy, 73 (3), pp. 404-409. https://doi. org/10.1016/j.saa.2008.09.006

Zephyrus, LXXXVIII, julio-diciembre 2021, 193-207 

from a Togatus Roman Sculpture found in Salamanca

Jiménez, M. C. and Rupidera, A. (2016): "Roman Togatus Statue Found in Salamanca”, Studia Historica: Historia Antigua, 34, pp. 139-165.

Jorge-Villar, S. E.; Rodríguez Temiño, I.; Edwards, H. G. M.; Jiménez Hernández, A.; Ruiz Cecilia, J. I. and Miralles, I. (2018): "The Servilia tomb: an architecturally and pictorially important Roman building", Archaeological and Anthropological Sciences, 10 (5), pp. 1207-1223. https://doi.org/10.1007/ s12520-016-0450-9

Krishnamurti, D. (1958): "The Raman spectrum of quartz and its interpretation". In Proceedings of the Indian Academy of Sciences-Section A, vol. 47, pp. 276-277.

Liverani, P. (2016): "La quarta dimensione della scultura: il colore". In Márquez, C. and OJedA, D. (eds.): Actas VIII Reunión de Escultura Romana en Hispania. Córdoba, pp. 107-124.

Martín Valls, R.; Benet, N. and Macarro, C. (1991): "Arqueología de Salamanca". In Santonja, M. (ed.): Del Paleolitico a la Historia. Salamanca: Museo de Salamanca, pp. 137-163.

Matson, D. W.; Sharma, S. K. and Philpotts, J. A. (1986): "Raman spectra of some tectosilicates and of glasses along the orthoclase-anorthite and nepheline-anorthite joins", American Mineralogist, 71, pp. 694-704.

McKeown, D. A. (2005). "Raman spectroscopy and vibrational analyses of albite: From $25^{\circ} \mathrm{C}$ through the melting temperature", American Mineralogist, 90 (10), pp. 1506-1517. https://doi.org/10.2138/ am.2005.1726

Noguera, J. M. (2002). "Técnicas en la escultura romana: materiales, imprimaciones y coloraciones. A propósito del grupo escultórico de Mazarrón”, Anales de Prehistoria y Arqueología, 17-18, pp. 373-412.

Østergaard, J. S. (2009): "The CPN Main Project 2008-2011: an outline”. In ØstergaArd, J. S. (ed.): Tracking Colour-The polychromy of Greek and Roman sculpture in the Ny Carlsberg Glyptotek. Copenhagen: Ny Carlsberg Glyptotek, pp. 68-73.
Østergaard, J. S. (2020): "Reflections on the Typology and Context of the Richmond Caligula". In Schertz, P. J. M. and Frischer, B. (eds.): New Studies on the Portrait of Caligula in the Virginia Museum of Fine Arts. Col. Monumenta Graeca et Romana, 26. Leiden-Boston: Brill, pp. 50-54. https://doi. org/10.1163/9789004417366_007

Pinto, J.; Prieto, A. C.; Coria-Noguera, J. C.; SanzMínguez, C. and Souto, J. (2020): "Investigating glass beads and the funerary rituals of ancient Vaccaei culture (ss. IV-I BC) by Raman spectroscopy", Journal of Raman Spectroscopy, November, pp. 1-16. https://doi.org/10.1002/jrs.6049

Sadezky, A.; Muckenhuber, H.; Grothe, H.; NiessNER, R. and Pöschl, U. (2005): "Raman microspectroscopy of soot and related carbonaceous materials: Spectral analysis and structural information”, Carbon, 43 (8), pp. 1731-1742. https://doi. org/10.1016/j.carbon.2005.02.018

Salinas de Frías, M.; Jiménez, M. C. and Nogales, T. (2016): "Personaje togado y espacio público de Salmantica”. En Márquez, C. and OJeda, D. (eds.): Actas VIII Reunión de Escultura Romana en Hispania. Córdoba, pp. 553-576.

Scott, J. F. and Porto, S. P. S. (1967): "Longitudinal and transverse optical lattice vibrations in quartz", Physical Review, 161 (3), pp. 903-910. https://doi. org/10.1103/PhysRev.161.903

Shebanova, O. N. and Lazor, P. (2003a): "Raman spectroscopic study of magnetite (FeFe2O4): A new assignment for the vibrational spectrum", Journal of Solid State Chemistry, 174 (2), pp. 424-430. https:// doi.org/10.1016/S0022-4596(03)00294-9

Shebanova, O. N. and Lazor, P. (2003b): "Raman study of magnetite (Fe3O4): Laser-induced thermal effects and oxidation", Journal of Raman Spectroscopy, 34 (11), pp. 845-852. https://doi.org/10.1002/ jrs. 1056

Verri, G.; Opper, T. and Deviese, T. (2010): “The 'Treu Head': a case study in Roman sculptural polychromy", Technical Research Bulletin, 4, pp. 39-54. 